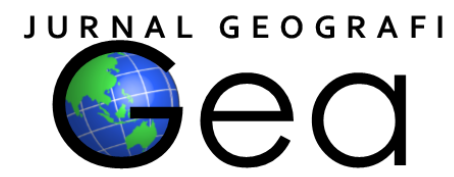

\title{
PEMANFAATAN PRODUK FOTOGRAMETRI DIGITAL UNTUK MEDIA PEMBELAJARAN
}

\author{
Muhammad Ihsan ${ }^{1}$, Dede Sugandi ${ }^{2}$ \\ ${ }^{1,2}$ Universitas Pendidikan Indonesia \\ ${ }^{1}$ muhammad.ihsan@upi.edu, ${ }^{2}$ dedesugandi@upi.edu
}

\begin{abstract}
The use of technology in instructional media has developed in the last two decades. One method that can be used to produce learning media is digital photogrammetry. By utilizing the concept of photogrammetry, which produces spatial information from the intercession of two overlapping photos, the product can be in the form of orthophoto maps and three-dimensional models. The results of photogrammetry have a visualization that represents the original object so that it is easier to study and analize. This study discusses the use of digital photogrammetry that can be used in four fields such as medicine, architecture, history and geography. The method used in this research is literature study method from the results of research on digital photogrammetry. The results obtained in this study are products produced from digital photogrammetry can assist in conducting learning such as helping in analyzing the anatomy of the body for the medical field, as a means of analyzing the shape and size of historic buildings for the field of architecture, analyzing the shape of reliefs and historical objects, and analyzing landforms and the dynamics of the earth for geography.
\end{abstract}

Keywords: learning media, digital photogrammetry

\begin{abstract}
ABSTRAK
Pemanfaatan teknologi dalam media pembelajaran telah berkembang dalam dua dekade terakhir. Salah satu metode yang dapat digunakan untuk menghasilkan media pembelajaran adalah dengan fotogrametri digital. Dengan memanfaatakan konsep fotogrametri, yaitu menghasilkan informasi spasial dari intersesi dua foto yang bertampalan, produk yang dihasilkan dapat berupa peta ortophoto dan model tiga dimensi. Hasil dari fotogrametri memiliki visualisasi yang merepresentasikan objek aslinya sehingga lebih mudah untuk diteliti maupun dianalisis. Penelitian ini membahas tentang pemanfaatan fotogrametri digital yang dapat digunakan untuk empat bidang seperti bidang kedokteran, arsitektur, sejarah, dan geografi. Metode yang digunakan dalam penelitian ini adalah metode studi pustaka dari hasil penelitian tentang fotogrametri digital. Hasil yang didapat dalam penelitian ini adalah produk yang dihasilkan dari fotogrametri digital dapat membantu dalam melakukan pembelajaran seperti membantu dalam menganalisis anatomi tubuh untuk bidang kedokteran, sebagai sarana dalam menganalisis bentuk dan ukuran bangunan bersejarah untuk bidang arsitektur, menganalisa bentuk relief dan objek sejarah, dan menganalisis bentuk lahan dan dinamika muka bumi untuk bidang geografi.
\end{abstract}

Kata kunci: media pembelajaran, fotogrametri digital 


\section{PENDAHULUAN}

Media pembelajaran pada dasarnya adalah suatu metode, perantara, maupun pengantar suatu informasi dari pemberi informasi ke penerima informasi. Peran media informasi sangat penting dalam pembelajaran, karena dengan media yang tepat serta menarik, para penerima informasi atau siswa mampu menyerap informasi dengan optimal. Banyak media informasi yang digunakan dalam dunia pendidikan, seperti media audio, visual, maupun yang sifatnya suatu kegiatan. Perkembangan teknologi secara langsung berdampak pada jenis media pembelajaran yang digunakan. Pemanfaatan konten yang bersifat digital mulai umum digunakan, karena informasi yang disajikan bersifat informatif dan fleksibel. Salah satu media informasi yang mulai banyak dikembangkan adalah media objek. Media objek merupakan media tiga dimensi yang menyampaikan informasi melalui ciri fisik, ukuran, bentuk, warna, fungsi, dan sebagainya (Susilana and Riyana, 2009).

Berdasarkan penelitian yang dilakukan oleh (Aji, 2016), pembelajaran dengan objek tiga dimensi mampu meningkatkan prestasi belajar hingga $54 \%$. Salah satu tantangan dalam pembelajaran objek tiga dimensi adalah proses pembuatan media. Proses pembuatan mode tiga dimensi memerlukan suatu teknik dan penguasaan perangkat lunak yang khusus. Salah satu teknik pembuatan model tiga dimensi adalah dengan menggunakan teknik fotogrametri digital. Fotogrametri digital pada dasarnya merupakan suatu teknik pemetaan dengan menggunakan kamera digital yang kemudian menghasilkan produk berupa peta dan model elevasi digital (Nex and Remondino, 2014). Perkembangan teknologi robotik dan computer vision pada fotogrametri digital menjadikan fotogrametri digital tidak hanya digunakan untuk pemetaan tetapi juga menghasilkan suatu objek tiga dimensi non terestris (Pérez Ramos and Robleda Prieto, 2015). Objek tiga dimensi tersebut dapat digunakan untuk media pembelajaran dari berbagai bidang studi.

Pada makalah ini, bidang studi yang dapat memanfaatkan teknologi fotogrametri digital antara lain, pembelajaran di bidang geografi, sejarah, kedokteran, dan arsitektur.
Keunggulan dari model tiga dimensi yang dihasilkan oleh fotogrametri digital adalah visualisasi yang menyerupai kondisi asli objek sehingga memudahkan untuk mengidentifikasi maupun analisis. Selain itu, model tersebut telah memiliki dimensi dan koordinat yang akurat sehingga dapat dilakukan pengukuran dimensi terhadap model tersebut.

\section{METODE PENELITIAN}

Metode yang digunakan dalam penelitian ini adalah metode studi pustaka yang menggunakan jurnal dan artikel ilmiah lainnya sebagai objek penelitian. Jenis penelitian yang digunakan adalah penelitian kualititatif, yaitu penelitian yang menghasilkan informasi baru berupa catatan deskriptif yang terdapat dalam pustaka yang diteliti (Mantra, 2008,30). Pemanfaatan Fotogrametri Digital dibagi dalam empat bidang yaitu, pembelajaran di bidang kedokteran, arsitektur, sejarah, dan geografi.

\section{Studi Literatur}

Media pembelajaran adalah segala sesuatu yang sudah berisi materi pembelajaran, yang memungkinkan seseorang untuk memanfaatkannya untuk belajar guna memperoleh pengetahuan, keterampilan, dan perubahan sikap (Suryani, 2016). Dengan adanya media pembelajaran, diharapkan kegiatan pembelajaran dapat bersifat interaktif dan lebih mudah dipahami. Media pembelajaran menurut (Riandi, 2014) harus memiliki lima syarat, antara lain: (1) Mampu menyederhanakan proses; (2) Mampu untuk memvisualkan atau mengkonkritkan hal-hal yang abstrak; (3) Biaya murah dengan bahan yang berada dari lingkungan sekitar kita (azas manfaat, bagi siswa memberi contoh untuk memanfaatkan barang bakas atau berfikir kreatif); (4)Mudah dirakit dan digunakan oleh siswa secara individual atau kelompok; (5) Penggunaan material dengan biaya yang rendah.

Salah satu jenis media pembelajaran adalah media objek. Media objek merupakan media tiga dimensi yang menyampaikan informasi tidak dalam bentuk penyajian, melainkan melalui ciri fisiknya sendiri seperti ukuran, bentuk, susunan, warna, fungsi dan 
sebagainya (Susilana and Riyana, 2009). Media objek dibagi menjadi dua jenis yaitu media objek sebenarnya dan media objek pengganti. Salah satu teknik dalam menghasilkan media objek adalah dengan Fotogrametri Digital. piksel antar foto yang saling bertampalan (Smith, Carrivick, dan Quincey, 2016). Kegiatan pemodelan tiga dimensi dengan fotogrametri digital dapat dilakukan dengan tahapan yang digambarkan pada gambar 1

Pemodelan tiga dimensi pada dasasrnya
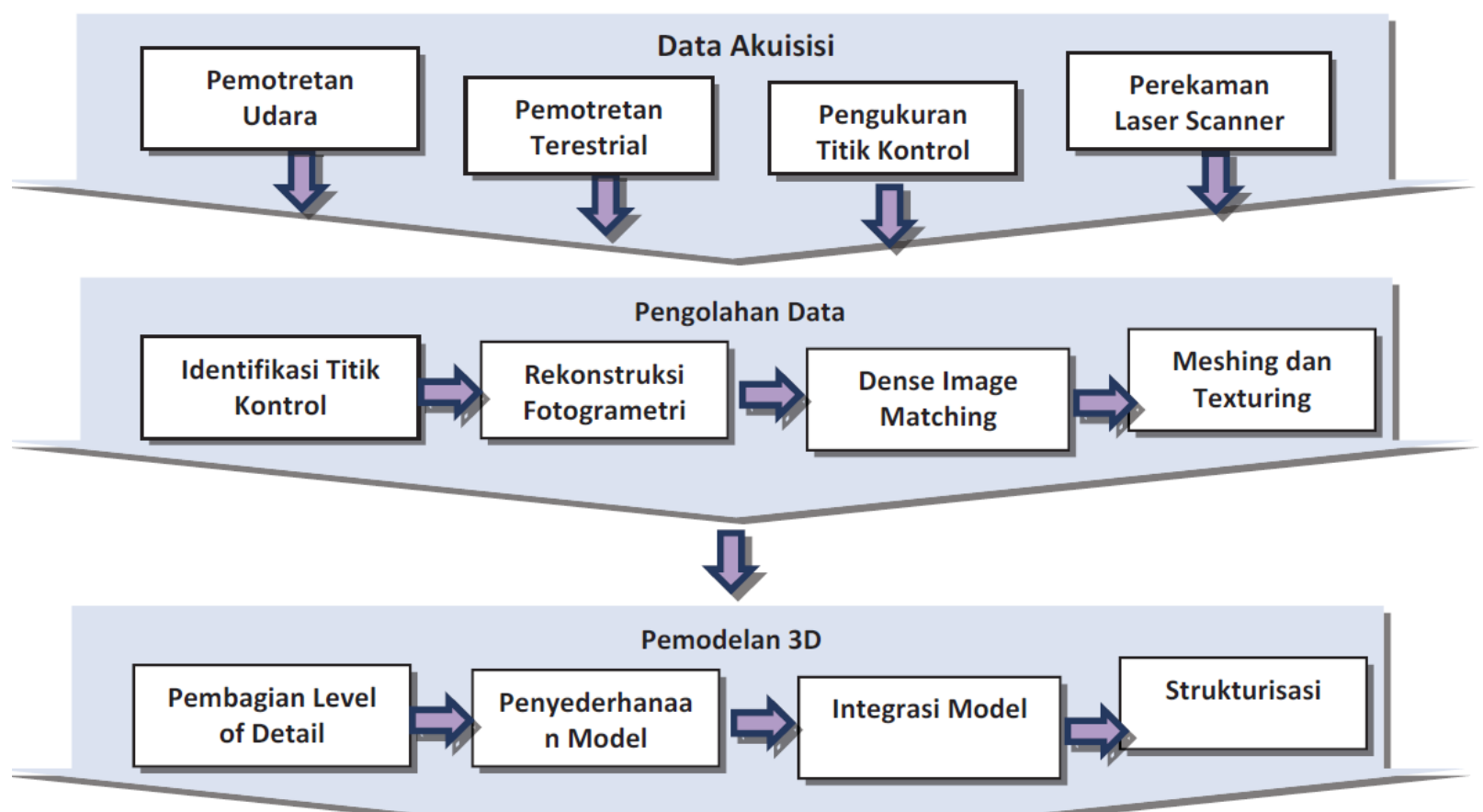

Gambar 1. Metode Pemodelan Tiga Dimensi dengan Fotogrametri Digital Kegiatan

sumber : Suwardhi et al,. 2016

Fotogrametri adalah seni, ilmu dan teknologi dalam memperoleh informasi yang terpercaya mengenai obyek-obyek dan lingkungan fisis, melalui proses perekaman, pengukuran dan penafsiran citra fotografik dan pola-pola energi elektromagnetik yang bercahaya dan gejala lainnya (American Society of Photogrammetry, 1934 pada Syaeful, 2007). Dari kedua aspek tersebut terdapat dua aspek penting yaitu aspek ukuran objek (kuantitatif) dan jenis objek (kualitatif). Seiring perkembangan zaman, fotogrametri kemudian dibagi menjadi dua yaitu fotogrametri analitik dan fotogrametri digitial. Fotogrametri digital adalah pemanfaatan foto digital sebagai sumber data pengukuran objek-objek foto dengan bantuan komputer (Syaeful, 2007). Luaran dari fotogrametri digital adalah peta foto, model elevasi digital, dan model tiga dimensi. Prinsip dari pemodelan tiga dimensi dari data fotogrametri digital adalah dengan melakukan rekonstruksi posisi kamera, triangulasi, dan penyocokan dibagi ke dalam tiga tahap, yaitu akuisisi data, pengolahan data dan pemodelan tiga dimensi. Pada proses akuisisi data, kegiatan pengambilan foto dilakukan dengan prinsip pertampalan ke muka dan ke samping. Pada proses pengolahan data dilakukan rekonstruksi berkas dan mozaiking sehingga menghasilkan titik tiga dimensi. Sedangkan tahapan terakhir yaitu tahapan pemodelan tiga dimensi.

\section{HASIL DAN PEMBAHASAN}

\section{Bidang Kedokteran}

Media pembelajaran dalam bidang kedokteran telah berkembang pesat seiring berkembangnya teknologi. Media pembelajaran yang digunakan dalam dunia kedokteran telah memanfaatkan prinsip fotogrametri digital dalam menghasilkan media pembelajaran. Pada awalnya, media yang digunakan adalah diagram, gambar, maupun video terkait fenomena kedokteran. Pada bidang kedokteran kebanyakan tehnik 
fotogrametri digunakan untuk menghasilkan objek tiga dimensi anatomi tubuh manusia (Petriceks, et al. 2018).

Hasil dari fotogrametri menghasilkan objek yang menyerupai serta akurat terhadap bentuk asli dari organ tersebut. Pada penelitian ini dilakukan pemodelan pada organ hati. Dengan fotogrametri, dapat dihasilkan model akurat terkait kondisi hati yang sehat juga yang mengalami tumor. Gambar 2 menampilkan kondisi anatomi hati.

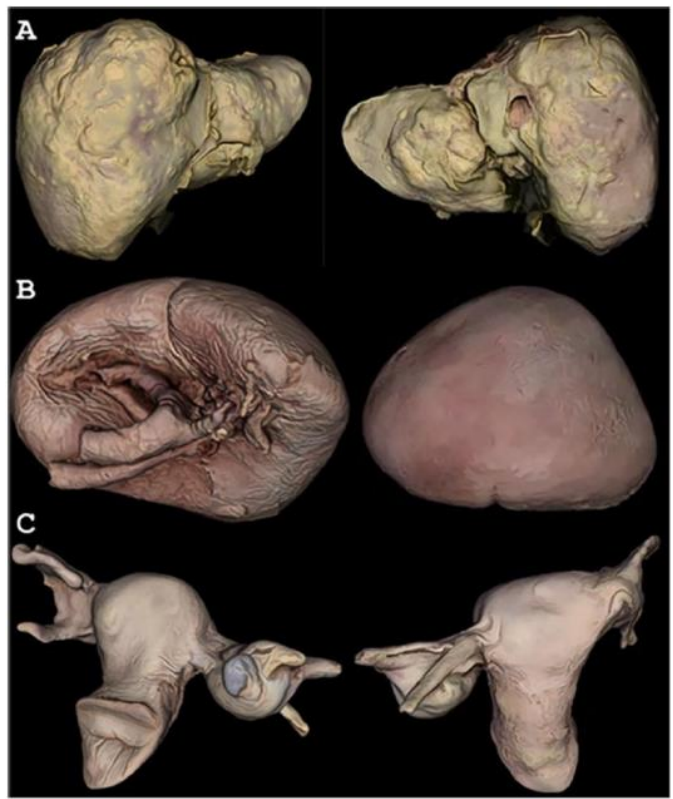

sumber : Petriceks et al.,. 2018

Gambar 1 Model Tiga Dimensi Anatomi

Tubuh

Respon mahasiswa terkait pembelajaran dengan media tiga dimensi cukup baik karena dengan bantuan smartphone, objek tiga dimensi dapat dilihat secara 360 derajat maupun diperbesar ukurannya sehingga objek yang ditampilkan bersifat fleksibel dan mudah untuk dipelajari Pemanfaatan prinsip fotogrametri digital dilakukan untuk analisis anomali pada tulang kaki di bidang kedokteran (Çatal Reis, 2018). Umumnya, teknologi yang digunakan untuk menganalisa kondisi tulang adalah menggunakan Computed Tomography (CT) dan Magnetic Resonance Imaging (MRI). Dengan menggunakan prinsip fotogrametri terbukti dapat menampilkan model sehingga kemudian dianalisis kondisi dari tulang kaki. Pada penelitian didapatkan bahwa dengan fotogrametri, kelainan pada tulang kaki dapat diketahui melalui algoritma edge detection dengan akurasi lebih dari 85\% (Catal Reis, 2018).

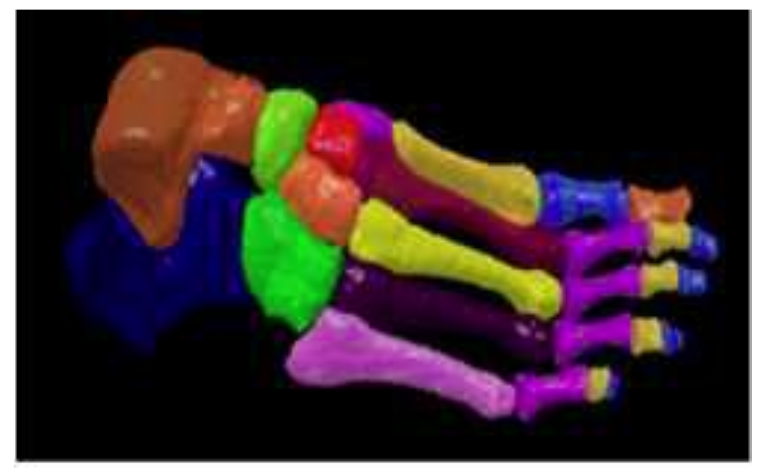

sumber : Çatal Reis, 2018

Gambar 2. Model Tiga Dimensi Tulang Kaki 2. Bidang Arsitektur

Metode pembelajaran dalam bidang arsitektur telah beralih dari metode tradisional yang berfokus pada persepsi hubungan tangan dan pensil menjadi teknologi digital yang menggunakan komputer sebagai perangkat utama pembelajaran (Tomasowa, 2011). Salah satu aspek penting dalam pembelajaran arsitektur adalah menguasi konsep perancangan. Konsep perancangan pada dasarnya proses penyelesaian masalah atau persoalan dengan menggunakan metode maupun cara yang tepat guna.

Salah satu konsep perancangan adalah preseden, yaitu melakukan studi banding maupun studi kasus pada beberapa masalah lain sebagai acuan maupun inspirasi arsitek dalam menyelesaikan masalah yang dihadapinya (Wuisang, 2015). Salah satu bentuk studi kasus antara lain mempelajari konsep arsitektur bangunan lain sehingga dapat menjadi opsi alternatif dalam pemecahan masalah. Kegiatan dalam mencari inspirasi tersebut dikemas dalam bentuk eksplorasi arsitektur (Purwantiasning 2014), eksplorasi arsitektur merupakan metode mengamati secara langsung suatu obyek sehingga siswa dapat turut aktif dalam kegiatan pembelajaran. Umumnya eksplorasi arsitektur dilakukan dengan terjun langsung ke lapangan, akan tetapi dengan menggunakan metode fotogrametri digital, memungkinkan siswa untuk menganalisa suatu obyek melalui model tiga dimensi yang interaktif.

Pemanfaatan fotogrametri digital untuk bidang arsitektur dapat membantu siswa dalam mengidentifikasi, mendeseain, maupun 
mengevaluasi suatu model engineering yang efektif, selain itu siswa dapat juga mengenali karakteristik bangunan dengan pembelajaran menggunakan model 3 Dimensi (Baik and Alitany, 2018). Konsep fotogrametri digital digunakan untuk studi karakteristik arsitektur bangunan bersejarah di Jeddah, Mekah. Pemanfaatan ini bermanfaat bagi penjelasan atau pemaparan suatu konstruksi bangunan. Gambar akan lebih terlihat menarik dan mudah dipahami dengan model 3 dimensi. Model 3 dimensi yang dihasilkan tertera seperti pada gambar 4 .

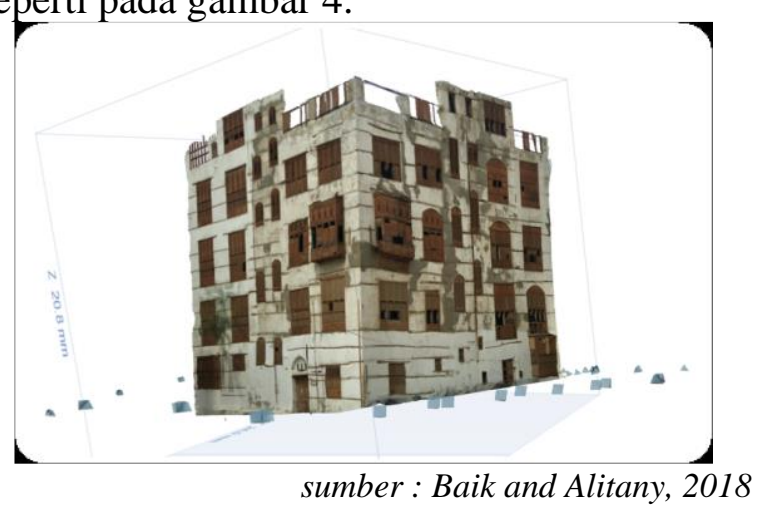

Gambar 3. Model Tiga Dimensi Gedung Arsitektur di Jeddah

Selain melakukan visualisasi, keunggulan dari model tiga dimensi ini adalah para siswa mampu melakukan pengukuran dimensi pada objek bangunan tersebut, dengan kemampuan ini, siswa dapat melakukan pengukuran rasio ukuran pada bagian-bagian bangunan. Penelitian yang dilakukan pada area bangunan konstruksi menampilkan bahwa dimensi bangunan yang dihasilkan sangat akurat, dengan akurasi dimensi di bawah $30 \mathrm{~mm}$ (Murtiyoso dan Grussenmeyer, 2017). Bentuk 3 Dimensi dari penelitian (Murtiyoso and Grussenmeyer, 2017) digambarkan pada gambar 5.

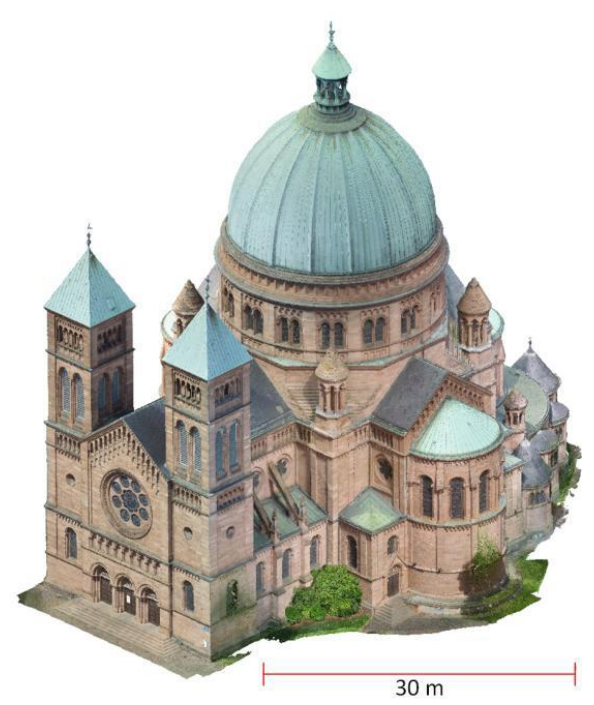

sumber : Murtiyoso and Grussenmeyer 2017

Gambar 4. Model Tiga Dimensi Katedral

\section{Bidang Sejarah}

Media pembelajaran yang digunakan dalam pembelajaran sejarah mulai berkembang selama beberapa tahun terakhir. Dengan teknologi komputasi yang semakin canggih, objek-objek bersejarah dapat divisualisasikan secara detail sehingga informasi yang dihasilkan sangat efektif (Suryani, 2016). Pemanfaatan komputer dalam melakukan visualisasi harus memperhatikan beberapa syarat antara lain Visibel, menarik, sederhana, berguna, tepat, logis, dan tersetruktur (Suryani, 2016).

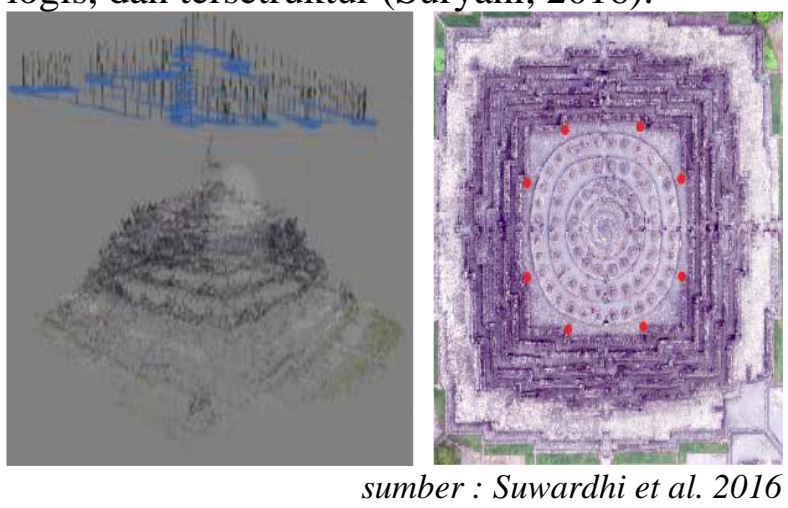

Gambar 6. Model Tiga Dimensi Candi Borobudur

Salah satu bentuk visualisasi yang mulai banyak digunakan dalam pembelajaran adalah dengan visualisasi model tiga dimensi, dengan model tiga dimensi, objek yang dipelajari dapat diidentifikasi dan dipelajari secara mendalam. Salah satu metode pembuatan model tiga dimensi adalah dengan teknik fotogrametri digital. Pemanfaatan fotogrametri digital mulai banyak dilakukan oleh beberapa peneliti, terdapat beberapa warisan budaya yang diteliti secara visual di 
Indonesia seperti Candi Borobudur (Suwardhi et al. 2016), Objek Candi Borobudur dapat dibuat visualisasi secara detail sehingga para siswa mampu mempelajari kondisi Candi Borobudur tanpa harus observasi langsung di lapangan. Model 3 Dimensi Candi Borobudur ditampilkan pada gambar 6 .

Selain model tiga dimensi, produk yang dihasilkan adalah peta resolusi tinggi skala tegak, sehingga para siswa mampu menginterpretasi kondisi Candi Borobudur dari tampilan bird view. Selain candi, pemanfaatan fotogrametri digital juga dapat digunakan untuk melakukan pemodelan benda bersejarah maupun rekonstuksi objek arkeologi.

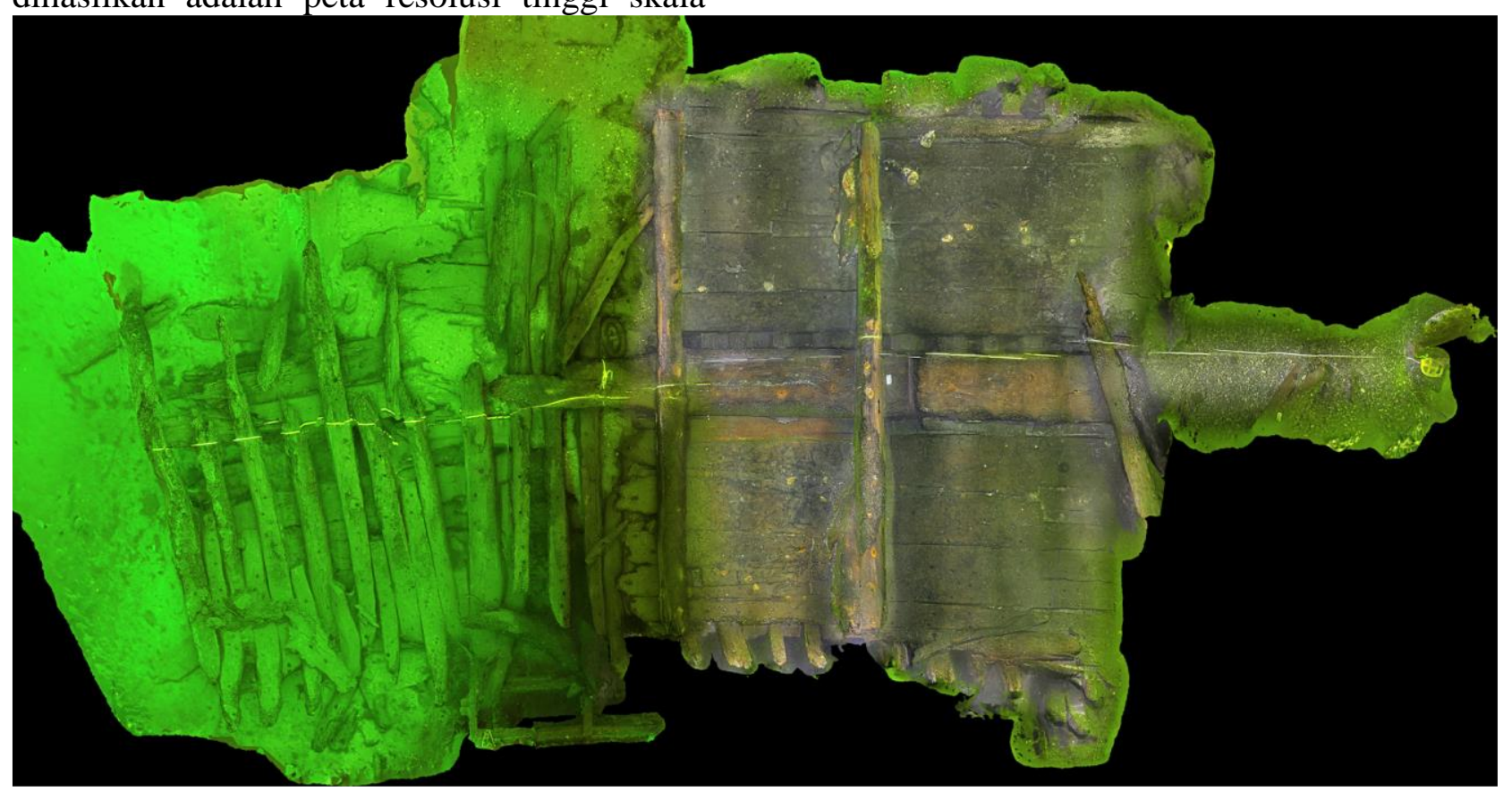

Gambar 7. Model Tiga Dimensi Kapal Karam

Pengembangan Fotogrametri Digital bawah air dapat dimanfaatkan untuk studi kapal karam Straatvaarder (Van Damme, 2015). Gambar 7 menampilkan hasil dari fotogrametri digital pada kasus kapal karam Straatvaarder.

Melalui informasi tersebut, Van Damme (2015) mampu menganalisis susunan kayu kapal sehingga dapat dijadikan suatu informasi pembelajaran tentang kondisikondisi kapal kayu pada zaman dahulu.

\section{Bidang Geografi}

Fotogrametri pada dasarnya merupakan suatu metode yang digunakan untuk melakukan penyajian kondisi topografi suatu daerah dengan tingkat akurasi tinggi, perkembangan fotogrametri semakin meningkat seiring berkembangnya teknologi di sektor kamera, robotic, computer vision, dan pesawat tanpa awak (Colomina and Molina, 2014). Pembelajaran geografi khususnya dalam kajian kewilayahan pasti memerlukan peta sebagai media pembelajaran.

Salah satu aspek pembelajaran dalam bidang geografi adalah menganalisis kondisi suatu wilayah dengan menggunakan peta dari fotogrametri digital. Keunggulan dari peta yang dihasilkan teknik fotogrametri adalah citra atau foto yang dihasilkan memiliki tingkat akurasi tinggi sehingga akan lebih memudahkan dalam menganalisa kondisi real suatu wilayah (Eisenbeiß, 2009). Selain peta, produk dari fotogrametri digital adalah model tiga dimensi suatu objek topografis sehingga kondisi dan visualisasi dapat didentifikasi serta lebih mudah dipahami. Visualisasi peta foto udara serta model elevasi digital Kawah Glasial Dig Tsho menghasilkan gambaran permukaan keseluruhan kawah yang mudah dideskripsikan (Westoby et al, 2012), seperti yang ditampilkan pada gambar 8 . 

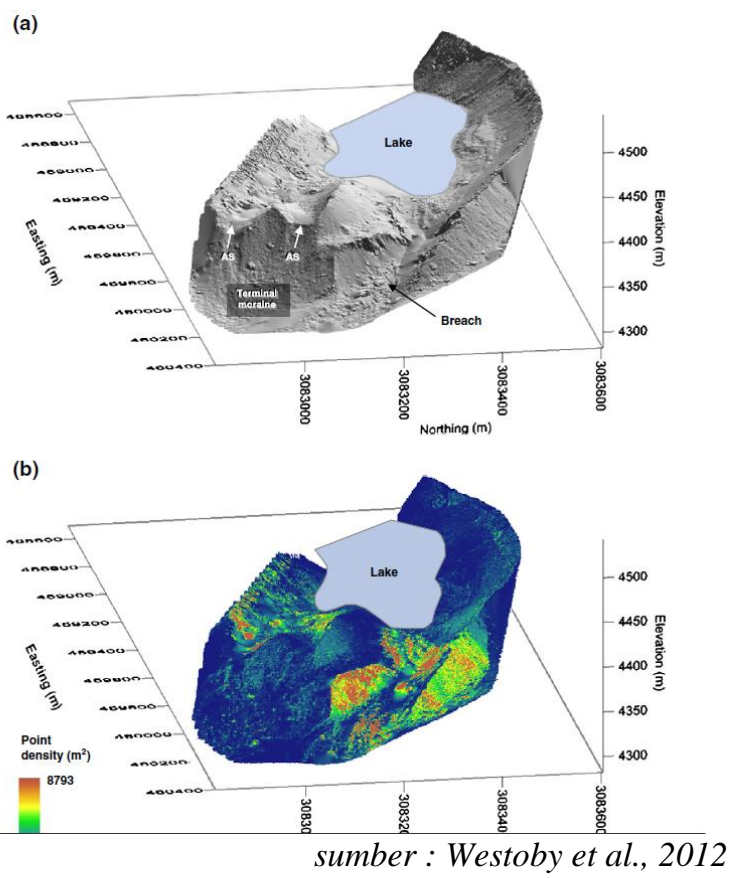

Gambar 5. Model Tiga Dimensi Kawah Glasial analisis spasial sehingga menghasilkan informasi baru.

Salah satu keunggulan model tiga dimensi dari fotogrametri digital adalah dapat menghasilkan suatu informasi spasial teliti terkait fenomena bencana alam. Penelitian yang dilakukan oleh (Wulan et al, 2017) tentang pemetaan kawasan terdampak bencana longsor dan banjir dapat memberikan suatu gambaran kondisi suatu kawasan yang terdampak serta mengetahui luasan dan perubahan tutupan lahan akibat bencana. Gambar menampilkan peta foto dampak bencana longsor

Pemanfaatan fotogrametri digital dalam bidang geografi yang lain antara lain, pemanfaatan untuk analisa kondisi perkotaan (Mohammed et al, 2014), pembaharuan kartografik (Carot et al, 2017), kajian wilayah

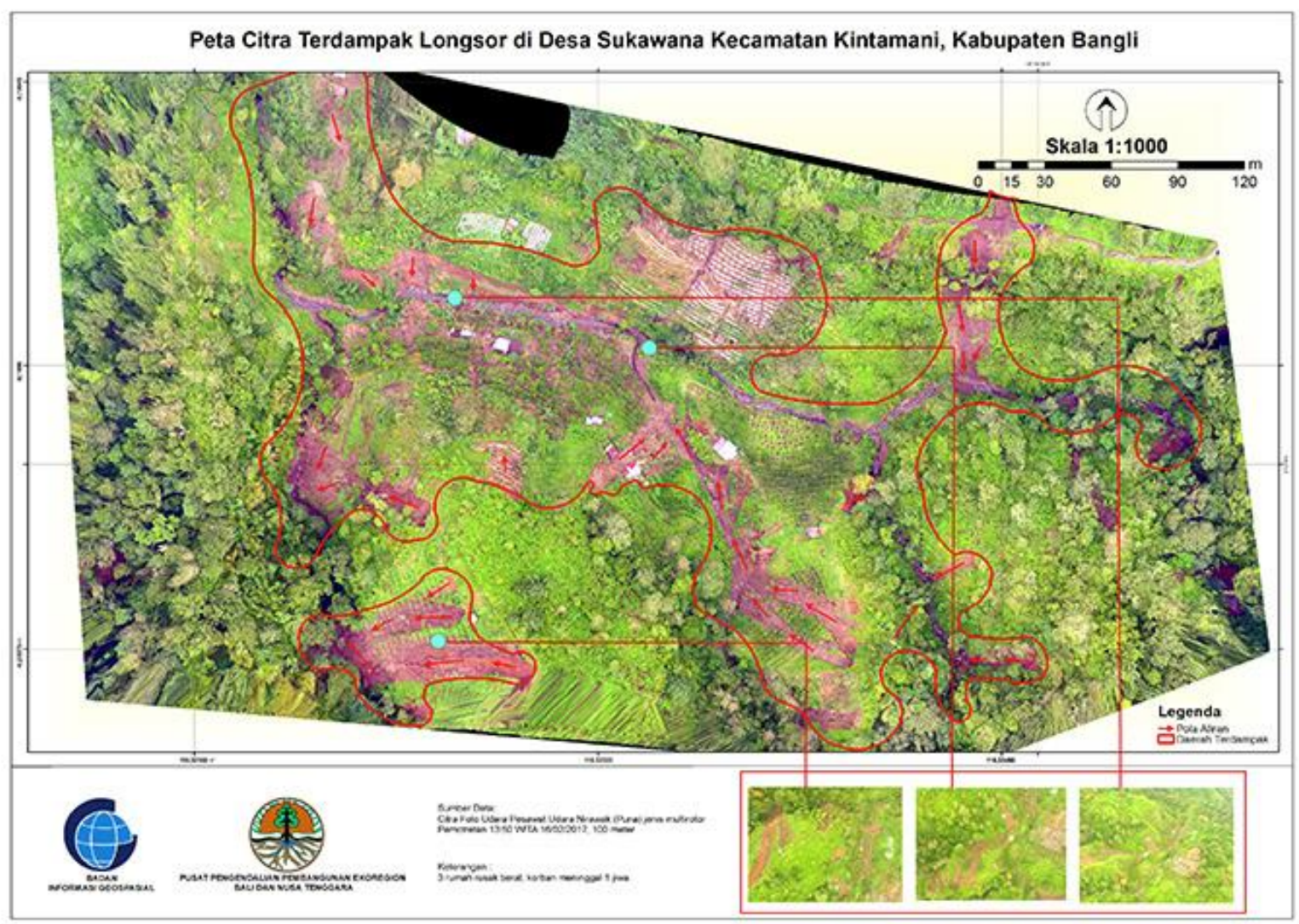

sumber : Wulan et al., 2017

Gambar 6. Peta Foto Wilayah Terdampak Bencana

Keunggulan dari model tiga dimensi yang dihasilkan dari Fotogrametri Digital adalah fleksibilitas dalam melakukan visualisasi, serta memiliki dimensi dan koordinat dengan akurasi orde sentimeter. Hal ini tentu akan membantu siswa dalam melakukan interpretasi serta melakukan pesisir (Drummond et al, 2015), hingga analisa sebaran hewan liar (Tremblay et al, 2017). Pemanfaatan teknologi yang terus menerus berkembang dapat membantu siswa dalam melakukan kajian spasial dengan lebih mendalam dan komprehensif. 


\section{SIMPULAN}

Model tiga dimensi yang dihasilkan dari fotogrametri digital mulai dikembangkan oleh beberapa peniliti untuk kepentingan pembelajaran. Model tiga dimensi mampu meningkatkan kemampuan siswa dalam menginterpretasi obyek-obyek seperti anatomi tubuh dan analisis kondisi jantung pada pembelajaran di bidang kedokteran. Selain itu dengan model tiga dimensi yang akurat, selain membantu dalam visualisasi dan identifikasi karakteristik arsitektur suatu objek, dapat pula digunakan untuk pengukuran dimensi.

Model tiga dimensi juga mampu menyajikan informasi detail terkait kondisi bangunan sejarah sehingga para siswa mampu mempelajari objek-objek sejarah. Selain itu dengan fotogrametri digital, kondisi geografis suatu wilayah dapat divisualisasikan dalam bentuk tiga dimensi sehingga para siswa mampu menginterpretasikan secara visual kondisi suatu daerah dan kemudian dianalisis dengan pendekatan spasial, Pemanfaatan fotogrametri digital dalam dunia pengembangan media pembelajaran harus terus dikembangkan dan disebarluaskan pada dunia pendidikan karena dapat membantu dalam penyampaian informasi secara efektif.

\section{REKOMENDASI}

Diperlukan penelitian lebih lanjut tentang pemanfaatan fotogrametri digital untuk pembelajaran di sekolah (SD,SMP,SMA) dengan media penyajian yang lebih variatif seperti penyajian di smartphone, menggunakan Virtual Reality atau Augmented Reality.

\section{DAFTAR PUSTAKA}

Aji, Wahyu Waskito. (2016). Penggunaan Media Pembelajaran Visual Tiga Dimensi (Sketchup) Untuk Meningkatkan Prestasi Belajar Pada Mata Pelajaran Gambar Konstruksi Bangunan Kelas XI Teknik Gambar Bangunan SMKN 2 Salatiga Tahun Pelajaran 2015/2016. Semarang.

Baik, A., and A. Alitany. (2018). From Architectural Photogrammetry Toward Digital Architectural Heritage Education. ISPRS. International
Archives of the Photogrammetry, Remote Sensing and Spatial Information Sciences (May) 42 (2018) 49-54. https://doi.org/10.5194/isprsarchives-XLII-2-49-2018.

Caroti, Gabriella, Andrea Piemonte, and Riccado Nespoli. (2017). UAV-Borne Photogrammetry: A Low Cost 3D Surveying Methodology for Cartographic Update. MATEC Web of Conferences 12009005 DOI: https://doi.org/10.1051/matecconf/201 712009005 .

Çatal Reis, Hatice. 2018. Bone Anomaly Of The Foot Detection Using Medical Photogrammetry. International Journal of Engineering and Geosciences 3 (1) (2006) 1-5. DOI: https://doi.org/10.26833/ijeg.333686.

Colomina, I., and P. Molina. (2014). Unmanned Aerial Systems for Photogrammetry and Remote Sensing: A Review. ISPRS Journal of Photogrammetry and Remote Sensing (June) $\quad 92 \quad 79-97 \quad$ DOI. https://doi.org/10.1016/j.isprsjprs.2014 .02.013.

Drummond, Christopher D, Mitchell D Harley, Ian L Turner, A Nashwan A Matheen, and William C Glamore. (2015). UAV Applications to Coastal Engineering. Australasian Coast and Ports Conferences 2015. 7 ISBN: 9781922107794.

\begin{tabular}{lcr} 
Eisenbeiß, Henri. & (2009). & $U A V$ \\
Photogrammetry. & \multicolumn{2}{c}{ Mitteilungen / } \\
Institut Für & Geodäsie & Und \\
Photogrammetrie & an & Der \\
Eidgenössischen & \multicolumn{2}{c}{ Technischen } \\
Hochschule Zürich & 105. Zürich: ETH, \\
Inst. für & Geodäsie & und \\
Photogrammetrie. ISBN 978-3-906467- & \\
86-3.
\end{tabular}
Photogrammetry. Mitteilungen / Institut Für Geodäsie Und Photogrammetrie an Der Hochschule Zürich 105. Zürich: ETH, nst. für Geodäsie und 86-3. 
Mantra, Bagoes, Ida. (2008). Filsafat Penelitian \& Metode Peneliian Sosial. Yogyakarta : Pustaka Pelajar

Mohammed, Farhan, Ahmed Idries, Nader Mohamed, Jameela Al-Jaroodi, and Imad Jawhar. 2014. UAVs For Smart Cities: Opportunities and Challenges. International Conference on Unmanned Aircraft Systems (ICUAS), Orlandi, FL, USA. 987-14799-23762/14 IEEE 267.

Murtiyoso, Arnadi, and Pierre Grussenmeyer. 2017. Documentation of Heritage Buildings Using Close-Range UAV Images: Dense Matching Issues, Comparison and Case Studies. The Photogrammetric Record (2017) 32 (159): 206-29 DOI: https://doi.org/10.1111/phor.12197.

Nex, Francesco, and Fabio Remondino. 2014. UAV for 3D Mapping Applications: A Review. Applied Geomatics 6 (1): 115. https://doi.org/10.1007/s12518013-0120-x.

Pérez Ramos, A., and G. Robleda Prieto. (2015). 3D Virtualization by Close Range Photogrammetry Indoor Gothic Church Apses. the Case Study of Church of San Francisco in Betanzos (La Coruña, Spain). ISPRS International Archives of the Photogrammetry, Remote Sensing and Spatial Information Sciences XL5/W4 (February): 50 201-6. DOI: https://doi.org/10.5194/isprsarchivesXL-5-W4-201-2015.

Purwantiasning, Ari Widyati. (2014). "Eksplorasi Arsitektur Sebagai Salah Satu Metode Dalam Proses Belajar Mengajar Mahasiswa Aktif Di Jurusan Arsitektur Universitas Muhammadiyah Jakarta," Seminar Nasional Sains dan Teknologi. 1-6. ISSN: 2407-1846.
Riandi. (2014). "Media Pembelajaran Biologi." UPI. Bandung.

Smith, M.W., J.L. Carrivick, and D.J. Quincey. 2016. Structure from Motion Photogrammetry in Physical Geography. Progress in Physical Geography (2016) 40 (2): 247-75. DOI: https://doi.org/10.1177/030913331561 5805.

Suryani, Nunuk. 2016. Pengembangan Media Pembelajaran Sejarah Berbasis IT. Sejarah dan Budaya: Jurnal Sejarah, Budaya, dan Pengajarannya (2016) 10 (2): 186-96. DOI: https://doi.org/10.17977/um020v10i22 $016 \mathrm{p} 186$.

Susilana, Rudi, and Cepi Riyana. (2009). Media Pembelajaran: Hakikat,Pengembangan,Pemanfaatan, Dan Penilaian. CV.Wacana Prima. Bandung

Suwardhi, Deni, Muhammad Mukhlisin, Dendy Darmawan, Shafarina Wahyu Trisyanti, and Yudi Suhartono. 2016. Survey dan Pemodelan 3D (Tiga Dimensi) untuk Dokumentasi Digital Candi Borobudur. Jurnal Konversi Cagar Budaya Borobudur. 102 10-22. DOI: https://doi.org/10.33374/jurnalk onservasicagarbudaya.v10i2.150

Syaeful, Bambang. (2007). Dasar-Dasar Fotogrametri. Yogyakarta: Universitas Negeri Yogyakarta.

Tomasowa, Riva. 2011. Pembelajaran Komputasi dalam Arsitektur Tingkat Awal. ComTech: Computer, Mathematics and Engineering Applications (2011) 2 (2): 1147. https://doi.org/10.21512/comtech.v2i2. 2928. 
Tremblay, Junior A., André Desrochers, Yves Aubry, Paul Pace, and David M. Bird. 2017. A Low-Cost Technique for Radio-Tracking Wildlife Using a Small Standard Unmanned Aerial Vehicle. Journal of Unmanned Vehicle Systems. (2017) 5 (3) 102-108. DOI: https://doi.org/10.1139/juvs-20160021 .

Van Damme, T. 2015. Computer Vision Photogrammetry For Underwater Archaeological Site Recording In A Low-Visibility Environment. ISPRS International Archives of the Photogrammetry, Remote Sensing and Spatial Information Sciences XL5/W5 (April). (2015) 405 231-38. https://doi.org/10.5194/isprsarchivesXL-5-W5-231-2015.

Westoby, M.J., J. Brasington, N.F. Glasser, M.J. Hambrey, and J.M. Reynolds. 2012. 'Structure-from-Motion'
Photogrammetry: A Low-Cost, Effective Tool for Geoscience Applications. Geomorphology. (2012) 179 $300-314$.

DOI:https://doi.org/10.1016/j.geomorp h.2012.08.021.

Wuisang, Cynthia E V. 2015. "Tinjauan Arsitektur: Bagaimana Merancang Arsitektur Dan Menkaji Metode Rancang Arsitek Nigel Cross". Media Matrasain. (2015) 123 35-43. ISSN: 1858-1137.

Wulan, Theresia Retno, Wiwin Ambarwulan, Anggara S. Putra, Mega D Putra, Dwi Maryanto, Ferrari Pinem, and Edwin Maulana. 2017. Pemetaan Cepat Kawasan Terdampak Bencana Longsor dan Banjir di Kabupaten Bangli, Provinsi Bali. Majalah Geografi Indonesia. (2017) 31 (2): 44. https://doi.org/10.22146/mgi.26230. 